\title{
PERTANGGUNGJAWABAN PIDANA ILLEGAL FISHING KORPORASI DALAM CITA-CITA INDONESIA POROS MARITIM DUNIA
}

\author{
Yuniarti Dwi Pratiwi ${ }^{1}$
}

\begin{abstract}
Abstrak: Permasalahan illegal fishing atau lebih dikenal dengan istilah illegal, unreported, and unregulated Fishing (IUU-Fishing) merupakan permasalahan yang telah lama mengakar di Indonesia. Hal ini dikarenakan Indonesia memiliki wlayah laut yang mencapai 2/3 dari seluruh wilayahnya dengan hasil laut yang cukup potensial. Potensi dari laut Indonesia juga didominasi oleh hasil ikannya, dengan lebih dari $45 \%$ spesies ikan di dunia berada di Indonesia. Beberapa alasan tersebut dapat dijadikan alasan kuat kenapa Indonesia menjadi salah satu wilayah yang sering mengalami illegal fishing. Kasus yang terjadi juga dapat dikatakan merupakan dampak kurang efektifnya penegakan hukum illegal fishing terutama untuk pihak korporasi. Di era pemerintahan Jokowi Indonesia mulai mencoba serius dalam pemberantasan tindak pidana illegal fishing. Hal ini sejalan dengan cita-cita Indonesia yakni mewujudkan visi Indonesia menjadi Poros Maritim Dunia. Meskipun demikian, apakah pemberantasan illegal fishing dalam era Presiden Jokowi menyentuh korporasi sebagai pelaku kejahatan?
\end{abstract}

Keyword: Illegal fishing, Korporasi, Poros Maritim

\section{METODE PENELITIAN}

Metode Penelitian yang digunakan dalam penulisan jurnal adalah deskriptif normatif. Dalam penulisan ini, penulis melakukan pengumpulan data-data untuk mendukung dan melengkapi penulisan jurnal ini. Langkah pertama dilakukan penelitian hukum normatif yang didasarkan pada hukum sekunder atau inventarisasi peraturan-peraturan yang berkaitan dengan tindak pidana perikanan. Selain itu juga digunakan bahan tertulis lainnya yang berkaitan dengan persoalan ini.

\section{LATAR BELAKANG}

Indonesia memiliki bentangan garis pantai dengan panjang $81.000 \mathrm{~km}$ persegi, sehingga menjadikan laut Indonesia dan wilayah pesisir Indonesia memiliki kandungan kekayaan dan sumber daya alam hayati laut yang sangat berlimpah, seperti ikan, terumbu karang, mangrove, dan sebagainya. ${ }^{2}$ Sejak awal dikumandangkan Deklarasi Djoenda (1957) yang memberikan keteguhan atas konsepsi Indonesia sebagai negara kelautan yang besar, berdaulat dan sejahtera, maka dari itu untuk menjaga kelestarian laut negara

\footnotetext{
${ }^{1}$ Yuniarti Dwi Pratiwi adalah anggota Lembaga Kajian Pertahanan untuk kedaulatan NKRI "KERIS" yang konsen menjadi pemerhati dibidang hukum dan pertahanan Indonesia. Penulis dapat dihubungi melalui email yuniartiibbas@gmail.com

Supriadi dan Alimudin, Hukum Perikanan di Indonesia, Sinar Grafika, Jakarta:2006, hal.2
}

ini, terutama guna menjaga sumberdaya ikan perlu didasarkan pada suatu Rencana Pengelolaan Perikanan (RPP). Hal ini sejalan dengan amanat Pasal 33 Undang Undang Dasar Tahun 1945, yang diatur lebih lanjut dalam Undang - Undang Nomor 31 Tahun 2004 dan perubahannya Undang - Undang Nomor 45 Tahun 2009 tentang Perikanan. Namun yang perlu diketahui, kondisi hingga hari ini tidak memberikan sesuatu yang cukup berarti bagi mereka yang menggantungkan hidupnya pada pengelolaan sumber daya pesisir dan laut Indonesia, seperti nelayan dan petambak tradisional. Mereka ini menjadi komunitas masyarakat yang rapuh secara ekonomi, pendidikan, kesehatan, dan hal-hal mendasar lainnya. Ini semua disebabkan salah satunya dari maraknya kasus pencurian ikan atau dengan kata lain adanya tindak kejahatan illegal fishing. Kondisi ini menunjukkan bahwa selama ini kurang maksimalnya pengawasan dan penegakan hukum terhadap para pelaku illegal fishing, terutama yang menyentuh korporasi. Oleh karena itu, sebagaimana visi yang dicanangkan oleh pemerintahan Joko Widodo yaitu menjadikan Indonesia sebagai Poros Maritim Dunia, apakah pemberantasan illegal fishing kali ini sudah menyentuh sebagai pelaku kejahatan sesungguhnya? Mengingat suatu negara dapat dikatakan sebagai Poros Maritim Dunia, salah satunya adalah dapat 
menjaga sumber daya laut dan kedaulatan negaranya.

\section{Pengertian Illegal fishing}

Illegal fishing adalah istilah populer yang dipakai untuk menyebut tindak pidana di bidang perikanan. Mengenai bentuk mana saja yang bisa dikategorikan sebagai tindak pidana illegal fishing adalah sesuatu yang perlu dikaji lebih lanjut, mengingat istilah ini tidak tersurat di dalam UndangUndang Perikanan. Namun, terminologl illegal fishing dapat dilihat dari pengertian secara harfiah yaitu dalam bahasa inggris. Illegal fishing berasal dari kata illegal yang berarti tidak sah atau tidak resmi. Fishing merupakan kata benda yang berarti perikanan. Sehingga illegal fishing merupakan tindakan mengambil, merogoh, mengail, memancing secara tidak sah. Pengawasan Sumber Daya Kelautan dan Perikanan Kementrian Kelautan dan Perikanan, memberi batasan pada istilah illegal fishing, yaitu pengertian illegal, unreported, unregulated (IUU) fishing yang secara harfiah dapat diartikan sebagai kegiatan perikanan yang tidak sah, kegiatan perikanan yang tidak diatur oleh peraturan yang ada, atau aktivitasnya tidak dilaporkan kepada suatu institusi atau lembaga pengelola perikanan yang tersedia. ${ }^{3}$ Pengertian illegal fishing diatas merujuk kepada pengertian yang dikeluarkan oleh International Plan of Action (IPOA) - Illegal, Unreported, Unregulated (IUU) Fishing yang diprakarsai oleh FAO dalam konteks implementasi Code of Conduct for Responsible Fisheries (CCRF). Sedangkan dalam UU Nomor 31 Tahun 2004 tentang Perikanan Jo. UU Nomor 45 Tahun 2009 mencantumkan definisi atau konsep "perikanan" yang mengandung pengertian:

Pasal 1 ayat (1) disebutkan, bahwa :

"Perikanan adalah semua kegiatan yang berhubungan dengan pengelolaan dan pemanfaatan sumber daya ikan dan lingkungannya mulai dari praproduksi, produksi, pengolahan, sampai dengan

\footnotetext{
${ }^{3}$ Pengawasan Sumber Daya Kelautan dan Perikanan,

"Mengenal IUU Fishing yang merugikan negara 3 Triliun Rupiah/Tahun, 12 Agustus 2016, http :

www.p2sdkpkendari.com
}

pemasaran, yang dilaksanakan dalam suatu sistem bisnis perikanan"

Definisi "perikanan" tersebut, mengandung arti kegiatan tidak hanya sekedar penangkapan ikan, tetapi juga termasuk kegiatan yang berhubungan dengan pengelolaan dan pemanfaatan sumber daya ikan dan lingkungannya mulai dari praproduksi, produksi, pengolahan, sampai dengan pemasaran. Setelah konsep illegal fishing yang dibuat oleh lembaga yang berwenang disinkronkan dengan konsep "perikanan" menurut Undang-Undang Nomor 31 Tahun 2004 tentang Perikanan Jo. Undang-Undang Nomor 45 Tahun 2009 maka dapat diketahui bahwa semua bentuk-bentuk kegiatan yang tidak sesuai dengan Undang-Undang tesebut dikatakan sebagai illegal fishing.

\section{Faktor Penyebab Illegal fishing}

1. Kedudukan ikan dunia (demand) meningkat tetapi di sisi lain pasokan ikan dunia menurun, sehingga terjadi overdemand terutama jenis ikan dari laut seperti tuna. Hal ini mendorong armada perikanan dunia berburu ikan secara legal dan illegal.

2. Disparitas (perbedaan) harga ikan segar utuh (whole fish) di negara lain dibandingkan di Indonesia cukup tinggi sehingga membuat masih adanya surplus pendapatan;

3. Fishing ground di negara lain sudah mulai habis, sementara di Indonesia masih menjanjikan, padahal mereka harus mempertahankan pasokan ikan untuk konsumsi dan harus mempertahankan produksi pengelolaan di negara tersebut tetap bertahan;

4. Laut Indonesia sangat luas dan terbuka, di sisi lain kemampuan pengawasan khususnya armada pengawasan nasional (kapal pengawas) masih sangat terbatas dibandingkan kebutuhan untuk menguasai daerah rawan. Luasnya wilayah laut yang menjadi yurisdiksi Indonesia dan kenyataan masih sangat terbuka ZEE Indonesia yang berbatasan dengan laut lepas (high seas) telah menjadi magnet penarik 
masuknya kapal-kapal ikan asing maupun lokal untuk melakukan illegal fishing;

5. Masih terbatasnya sarana dan prasarana pengawasan serta SDM pengawasan khususnya dari sisi sekuritas;

6. Persepsi dan langkah kerja sama aparat penegak hukum dalam penanganan perkara tindak pidana perikanan masih belum solid, terutama dalam hal pemahaman tindakan hukum dan komitmen operasi kapal pengawas di ZEE. ${ }^{4}$

\section{TINDAK PIDANA ILLEGAL FISHING DI WILAYAH INDONESIA}

Merujuk pada pengertian illegal fishing menurut Code of Conduct for Responsible Fisheries (CCRF) yang diprakarsai oleh FAO maka tindakan illegal fishing dibagi menjadi sebagai berikut:

a. Illegal fishing, yaitu kegiatan berupa :

1) Penangkapan ikan tanpa izin; 2) Penangkapan ikan dengan menggunakan izin palsu; 3) Penangkapan ikan dengan menggunakan alat tangkap terlarang; 4) Penangkapan ikan dengan jenis (spesies) yang tidak sesuai dengan izin.

b. Unreported fishing, yaitu kegiatan penangkapan ikan yang :

1. Tidak pernah dilaporkan atau dilaporkan secara tidak benar kepada instansi yang berwenang dan tidak sesuai dengan peraturan perundang-undangan;

2. Dilakukan di area yang menjadi kompetensi organisasi pengelolaan perikanan regional, namun tidak pernah dilaporkan atau dilaporkan secara tidak benar dan tidak sesuai dengan prosedur pelaporan dari organisasi tersebut. Kegiatan unreported fishing yang umum terjadi di Indonesia :

1. Penangkapan ikan yang tidak melaporkan hasil tangkapan yang sesungguhnya atau pemalsuan data tangkapan;

\footnotetext{
${ }^{4}$ Nunung Mahmudah, Illegal Fishing Pertanggungjawaban Pldana Korporasi di Wilayah Perairan Indonesia, Jakarta, Sinar Grafika, hal 20
}

2. Penangkapan ikan yang langsung dibawa ke negara lain (transhipment di tengah laut).

c. Unregulated fishing, yaitu kegiatan penangkapan ikan:

1. Pada suatu area atau stok yang belum diterapkan ketentuan pelestarian dan pengelolaan, dalam hal ini kegiatan penangkapan tersebut dilaksanakan dengan cara yang tidak sesuai dengan tanggung jawab negara untuk pelestarian dan pengelolaan sumber daya ikan sesuai hukum internasional;

2. Pada area yang menjadi kewenangan organisasi pengelolaan perikanan regional yang dilakukan oleh kapal tanpa kewarganegaraan atau yang mengibarkan bendera suatu negara yang tidak menjadi anggota organisasi tersebut, hal ini dilakukan dengan cara yang tidak sesuai atau bertentangan dengan ketentuan pelestarian dan pengelolaan dari organisasi tersebut.

Kegiatan unregulated fishing di perairan Indonesia, antara lain masih belum diaturnya :

1. Mekanisme pencatatan data hasil tangkapan dari seluruh kegiatan penangkapan ikan yang ada;

2. Wilayah perairan yang diperbolehkan dan dilarang;

3. Kegiatan penangkapan ikan menggunakan modifikasi dari alat tangkap yang dilarang. ${ }^{5}$

Sementara itu Undang-Undang Positif mengidentifikasikan tindak pidana dalam bidang perikanan yakni Kejahatan dan Pelanggaran sebagaimana tertuang dalam Pasal 103 Undang-Undang Nomor 31 Tahun 2004 tentang Perikanan jo. UndangUndang Nomor 45 Tahun 2009. ${ }^{6}$

Tinjauan Hukum Pertanggungjawaban Pidana Korporasi Sebagai Pelaku Illegal fishing

\footnotetext{
ibid, hal-81-82

${ }^{6}$ Undang-Undang Nomor 31 Tahun 2004 tentang

Perikanan Jo. Undang-Undang Nomor 45 Tahun 2009
} 
Pada saat ini, korporasi merupakan bentuk organisasi bisnis yang paling penting. Korporasi berkembang menjadi institusi, baik berupa organisasi publik maupun swasta yang tujuannya mencari keuntungan. Seiring dengan peran korporasi yang semakin besar dalam dunia ekonomi, dampak negatif yang ditimbulkan dari kegiatan korporasi juga semakin besar. Dengan demikian beberapa negara terutama yang perekonomiannya baik, mulai mencari cara untuk bisa meminimalisasi atau mencegah dampak negatif, salah satu caranya dengan menggunakan instrumen hukum pidana (bagian dari hukum publik). Di Indonesia peraturan perihal korporasi menjadi subjek hukum, khususnya sebagai subjek hukum tindak pidana kejahatan illegal fishing telah diatur dalam Undang-Undang Nomor 31 Tahun 2004 tentang Perikanan jo, UndangUndang Nomor 45 Tahun 2009. Dalam Pasal 84-100 UU Nomor 31 Tahun 2004 tentang Perikanan jo. Undang-Undang Nomor 45 Tahun 2009 dicantumkan bahwa "Setiap Orang" sebagai pelaku tindak pidana kejahatan illegal fishing. Rumusan perihal pertanggung jawaban pidana juga tertuang dalam Pasal 101 Undang-Undang Nomor 45 tahun 2009 yang menyebutkan bahwa :

"Dalam hal tindak pidana perikanan dilakukan oleh korporasi, tuntutan dan sanksi pidananya dijatuhkan terhadap pengurusnya, dan pidana dendanya ditambah sepertiga dari pidana yang dijatuhkan".

Dengan rumusan demikian, meskipun korporasi diakui sebagai pelaku suatu tindak pidana, tetapi korporasi itu sendiri tidak dapat dimintakan pertanggungjawaban pidana. Pengaturan ini menimbulkan kelemahan. $\mathrm{Hal}$ ini dikarenakan, dalam kasus-kasus yang merupakan tindak pidana illegal fishing, penjatuhan pidana penjara atau denda "hanya" kepada pihak pengurus korporasi. Penjatuhan pidana kepada pengurus korporasi ini dirasa tidak cukup untuk memberikan jaminan bahwa korporasi tersebut tidak melakukan tindakan serupa di kemudian hari. Akibatnya penanganan kasus-kasus tindak pidana perikana sulit dituntaskan, khususnya yang melibatkan pihak korporasi. $^{7}$

\section{Tantangan Pembertantasan IIlegal fishing dl Indonesia}

1. Adanya Rezim Hukum yang Berbeda (legal rezime).

Berbicara perihal rezim hukum yang berlaku di laut terdapat dua kepentingan, yaitu kepentingan nasional dan internasional. Hal ini berarti bahwa dalam melaksanakan penegakan hukum di laut selain berdasarkan hukum nasional tetapi juga perlu memperhatikan kaidahkaidah hukum internasional yang berlaku. Maka dari itu, rezim hukum yang berlaku di wilayah laut membawa hak dan kewenangan negara yang berbeda pula. Misalnya hak dan kewenangan negara di laut di mana berlaku rezim kedaulatan negara seperti di perairan kepulauan dan laut teritorial, berbeda di wilayah laut di mana berlaku yurisdiksi tertentu atau hak-hak berdaulat seperti di wilayah laut Zona Tambahan, ZEE, dan landas kontinen. ${ }^{8}$

2. Aparat Penegak Hukum

Dalam hal ini berkaitan pada aspek kuantitas dan kualitas aparat penegak hukum. dalam menangani kasus-kasus illegal fishing di wilayah perairan Indonesia. Kekurangan baik dari segi kuantitas maupun kualitas aparat penegak hukum akan sangat mempengaruhi efektivitas penegakan hukum di perairan Indonesia. Selain itu, lemahnya koordinasi antar Instansi Penegak Hukum dapat menimbulkan tumpang tindih kewenangan dan kebijakan masing - masing, sehingga sangat rawan menimbulkan konflik kepentingan. Penegakan hukum yang tidak terkoordinasi merupakan salah satu kendala dalam penanggulangan kejahatan illegal fishing.

3. Rumusan Sanksi Pidana

\footnotetext{
${ }^{7}$ Pdf Skripsi Pertanggung Jawaban Korporasi (Coporate Liability) dalam Tindak Pidana Perikanan, Aulia Ariffandi, Fakultas Hukum Universitas Sumatera Utara,

http://repository.usu.ac.id/bitstream/123456789/36720/1/09 E02782.pdf

${ }^{8}$ Nunung Mahmudah, Illegal Fishing Pertanggung Jawaban Korporasi Nunung Mahmundah. Sinar Grafika, Jakarta, hal 117
} 
Rumusan sanksi pidana dalam Undang - Undang Nomor 31 Tahun 2004 jo Undang - Undang Nomor 45 Tahun 2009 tentang Perikanan yang memiliki sanksi pidana denda yang sangat berat dibandingkan dengan ketentuan pidana yang lain, ternyata belum memberikan efek jera kepada pelaku kejahatan illegal fishing. Ancaman hukuman penjara yang paling berat 6 (enam) tahun bagi pelaku yang melakukan penangkapan ikan tanpa memiliki atau membawa SIPI (Surat ljin Penangkapan Ikan) dan paling berat 7 (tujuh) tahun bagi yang melakukan pemalsuan dan memakai ijin palsu berupa SIUP, SIPI, SIKPI. Pidana denda yang paling banyak $R p$. 20.000.000.000,- (dua puluh milyar rupiah). Rumusan sanksi dalam Undang - Undang ini tidak mengatur rumusan sanksi paling rendah atau minimum sehingga seringkali sanksi pidana yang dijatuhkan tidak memberi efek jera kepada pelaku. Demikian juga belum diatur tentang sanksi pidana bagi Korporasi serta sanksi pidana tambahan terutama kepada tindak pidana pembiaran. ${ }^{9}$

\section{Sanksi Alternatif Terhadap Korporasi Sebagai Pelaku Illegal fishing}

1. Sanksi bernilai uang

a. Mengganti keuntungan ekonomis (recoups any economic benefit) yang diperoleh sebagai hasil dari kejahatan;

b. Mengganti (recover) semua atau sebagian biaya pengusutan atau penyidikan dan melakukan perbaikan (reparation) setiap kerugian yang ditimbulkan;

c. Denda.

2. Pidana tambahan berupa :

a. Larangan melakukan perbuatan atau aktivitas yang menyebabkan berkelanjutnya atau terulanginya kejahatan itu;

b. Perintah untuk mengakhiri atau tidak melanjutkan kegiatan (untuk sementara atau selamanya),

\footnotetext{
${ }^{9}$ http://amrmulsin.blogspot.co.id/2014/05/makalah-illegalfishing.html (diakses pada tanggal 18 Agustus 2016 pukul 12:30 WIB)
}

pencabutan izin kegiatan, pembubaran usaha bisnis;

c. Perampasan kekayaan (property asset) dan hasil kejahatan dengan memberi perlindungan hak-hak pihak ketiga yang bonafider;

d. Mengeluarkan atau mendiskualifikasi terpidana atau korporasi dari kontrak pemerintah, keuntungan fiscal, atau subsidi;

e. Memerintahkan pemecatan manajer dan mendiskualifikasi atau membatalkan petugas dari jabatannya;

f. Mengharuskan terpidana memenuhi syarat-syarat atau kondisi yang ditetapkan oleh pengadilan untuk mencegah terpidana mengulangi perbuatannya;

g. Memerintahkan publikasi faktafakta yang berhubungan dengan putusan pengadilan;

h. Memerintahkan terpidana untuk memberitahu orang-orang yang dirugikan oleh perbuatannya;

i. Memerintahkan terpidana (apabila merupakan organisasi) untuk memberitahukan kepada publik di semua negara tempat beroperasinya organisasi tersebut, seperti kepada cabangcabangnya, kepada para direktur, petugas, manajer, dan karyawannya, mengenai pertanggungjawaban atau sanksi yang dikenakan kepadanya;

j. Memerintahkan terpidana untuk melakukan pelayanan atau kerja sosial (community service)

Sanksi-sanksi tersebut dapat dijadikan alternatif sebagai sanksi terhadap korporasi agar korporasi menjadi jera dan tidak akan mengulangi perbuatannya lagi. Disamping itu, korporasi lain tidak berpikir untuk melakukan perbuatan yang sama)

\section{PENTINGNYA PEMBERATASAN ILLEGAL FISHING DALAM VISI INDONESIA POROS MARITIM DUNIA}

Salah satu gagasan cemerlang Presiden Jokowi yang mendapat dukungan publik dengan penuh antusiasme adalah tekadnya untuk mewujudkan Indonesia sebagai PMD (Poros Maritim Dunia. Visi 
Poros Maritim Dunia ini kelak diharapkan Indonesia menjadi negara maju, sejahtera, dan berdaulat berbasis pada ekonomi kelautan, hankam dan budaya maritim. Visi Presiden Rl ke-7 itu sangat tepat dan beralasan. Pasalnya, Indonesia merupakan negara kepulauan terbesar di dunia yang tersusun atas lebih dari 17.000 pulau, dirangkai oleh $95.181 \mathrm{~km}$ garis pantai (terpanjang kedua setelah Kanada), dan sekitar $70 \%$ wilayahnya berupa laut. Di wilayah pesisir dan laut itu terkandung beragam SDA (Sumber Daya Alam) dan jasa-jasa lingkungan (environmental services) yang sangat besar dan belum dimanfaatkan secara optimal. ${ }^{10}$ Kekayaan SDA dan jasa-jasa lingkungan kelautan tersebut dapat kita dayagunakan untuk kemajuan dan kemakmuran bangsa melalui 11 sektor ekonomi kelautan: (1) perikanan tangkap, (2) perikanan budidaya, (3) industri pengolahan hasil perikanan, (4) industri bioteknologi kelautan, pertambangan dan energi (ESDM), (6) pariwisata bahari, (7) hutan mangrove, (8) perhubungan laut, (9) sumberdaya wilayah pulau-pulau kecil, (10) industri dan jasa maritim, dan (11) SDA non-konvensional. ${ }^{11}$

Mengacu pada visi Presiden Jokowi tentang PMD di atas, pada dasarnya ada lima kelompok kebijakan dan program utama yang mesti dikerjakan, salah satunya adalah pemberantasan illegal fishing dan berbagai kegiatan ilegal lainnya - Pemberantasan illegal fishing menjadi penting, dikarenakan tindakan Illegal, Unreported, and Unregulated (IUU) fishing tidak hanya meliputi pencurian ikan dan kesejahteraan nelayan, namun juga meliputi kedaulatan Negara Indonesia, karena tindakan illegal fishing juga mempengaruhi perbatasan Negara Indonesia dengan negara lain. Kedaulatan Negara Indonesia sangat diperlukan demi mewujudkan visi Poros Maritim Dunia yang digagas oleh Presiden Joko Widodo.

\section{KESIMPULAN}

Praktik Kejahatan illegal fishing di wilayah perairan Indonesia selama ini kian

http://www.republika.co.id/berita/koran/pareto/15/04/06/nmo qp b-jalan-indonesia-menuju-poros-maritim-dunia (diakses pada tanggal 19 Agustus 2016) marak. Hal ini menimbulkan kerugian yang sangat besar bagi bangsa dan negara pada umumnya serta masyarakat pesisir pada khususnya. Illegal fishing dalam peraturan yang ada merupakan "kejahatan" maupun "pelanggaran" sebagaimana tertuang dalam Undang-Undang Nomor 31 Tahun 2004 tentang Perikanan jo. UndangUndang Nomor 45 Tahun 2009 tentang Perubahan Atas Undang-Undang Nomor 31 Tahun 2004. Pelaku tindak pidana illegal fishing di wilayah Indonesia pada umumnya adalah setiap orang yang diartikan "perseorangan" atau "korporasi". Melihat rumusan dalam perundangundangan yang berlaku, sistem pertanggungjawaban pidana korporasi dikenakan pada pengurus atau pembuat korporasi. Akan tetapi, meskipun korporasi diakui sebagai palaku suatu tindak pidana, korporasi itu sendiri tidak dapat dimintakan pertanggungjawaban pidana. Pengaturan demikian dapat menimbulkan banyak kelemahan. Logikanya untuk kasus-kasus tertentu dimana keuntungan yang diperoleh perusahaan besar sedemikian besar/atau kerugian yang ditanggung masyarakat sedemikian besar, maka pengenaan pidana penjara/denda "hanya" kepada pihak pengurus korporasi akan menjadi tidak seimbang. Disamping itu, pengenaan biaya kepada pengurus korporasi juga tidak cukup memberikan jaminan bahwa korporasi tersebut tidak akan kembali mengulangi perbuatannya kembali dikemudian hari. Oleh karena itu sehingga mengakibatkan kasus-kasus tindak pidana illegal fishing sulit dituntaskan, terutama yang melibatkan pihak korporasi.

Atas dasar inilah, dan demi asas kepentingan umum, pemerintah harus meletakkan dasar hukum yang kuat dalam penindakan korporasi yang terlibat dalam illegal fishing. Hal yang perlu dilakukan oleh pemerintah adalah mengkaji kembali peraturan perundangan-undangan yang berlaku, dengan memasukkan substansi hukum Sistem Pertanggungjawaban Pidana yang memungkinkan menuntut korporasi dan meminta pertanggungjawaban menurut hukum pidana. Pemerintah dalam hal ini, harus membuat sebuah formulasi hukum yang bisa menundukkan korporasi sebagai 
tersangka, terdakwa, dan menjatuhkan sanksi pidana.

\section{TINJAUAN PUSTAKA}

Supriadi, Alimudin, Hukum Perikanan di Indonesia, Sinar Grafika, Jakarta : 2006

Paradigma Geomaritim Strategi Mewujudkan Indonesia Sebagai Poros Maritim Dunia dalm Perspektif Geografi, Badan Informasi Geospasial

Nunung Mahmudah, Illegal fishing Pertanggungjawaban Pldana Korporasi di Wilayah Perairan Indonesia, Sinar Grafika, Jakarta :2015

Harsono, Boedi, Hukum Agraria Indonesia (Sejarah Pembentukan Undang Undang Pokok Agraria, Isi dan Pelaksanaannya), Jilid 1, Hukum Tanah Nasional, Jakarta: Djambatan, Edisi Revisi 2007.

Undang-Undang Nomor 31 Tahun 2004 tentang Perikanan

Undang-Undang Nomor 45 Tahun 2009 tentang Perubahan Atas UndangUndang Nomor 31 Tahun 2004 Tentang Perikanan

Undang-Undang Dasar Tahun 1945

http://repository.usu.ac.id/bitstream/123456 789/36720/1/09E02782.pdf Skripsi

Pertanggung Jawaban Korporasi (Coporate Liability) dalam Tindak Pidana Perikanan, Aulia Ariffandi, Fakultas Hukum Universitas Sumatera Utara

http://www.republika.co.id/berita/koran/pare to/15/04/06/nmdqpb-jalan-indonesiamenuju-poros-maritim-dunia (diakses pada tanggal 19 Agustus 2016)

http : www.p2sdkpkendari.com Pengawasan Sumber Daya Kelautan dan Perikanan, "Mengenal IUU Fishing yang merugikan negara 3 Triliun Rupiah/Tahun, (diakses 12 Agustus 2016) 